\title{
Obstacles build communication and coordination of institution in the university: a qualitative study
}

\author{
Zahara Tussoleha Rony ${ }^{1 *}$, Suharjuddin², Tatar Bonar Silitonga ${ }^{3}$ \\ ${ }^{1,2}$ Universitas Bhayangkara Jakarta Raya, Jakarta, Indonesia \\ ${ }^{3}$ Universitas Pertahanan, Bogor, Indonesia \\ ${ }^{*}$ Corresponding author: zahara.tussoleha@dsn.ubharajaya.ac.id
}

\begin{abstract}
The Corona Virus Pandemic forces most organizations to implement systems and policies that are adjusted to government regulations and appeals, including work from home, including at a research institute in private universitypies in Indonesia. For the systems and policies to be implemented effectively, the leadership makes adjustments, especially in managing communications. Communication management is an important point during this transitional period because it has an impact on the coordination and results of work. Ineffective communication causes the institution's performance to be less than optimal. The purpose of this research is to describe the practice of communication management and coordination carried out by the leadership of an institution at a private university in Jakarta. The research method chosen was a case study approach, 11 informants were determined by purposive and snowball sampling. The results of this research show that the communication and coordination carried out by the leadership of the institution is not optimal, besides that it is limited to taking the initiative in confirming and providing a response, resulting in delays in completing their work. The fact in the field of leadership has not adjusted the style of communication and coordination during the new normal. Comprehensive communication and coordination skills need serious attention because these abilities have an impact on institutions in building a culture of synergy.
\end{abstract}

Keywords: Adaptation; collaboration; coordination; leader; organizational communication JEL Classification Code: D83, L20, L21 DOI: 10.20885/isb.vol25.iss1.art7

\section{Introduction}

The virus named COVID-19 first appeared in Wuhan, China, around December 2019. The arrival of COVID-19 made the outbreak known as the Coronavirus Pandemic quite devastating all aspects of social and economic life and had a direct impact on the rate of change in the world of work. Activities to complete work are allowed from home or work from home. In fact, it is not only in the world of work that the world of education also practices the same thing as learning from home (Tian et al., 2020).

Remote work has made the transformation of digital technologies in the world of work used faster, especially in the midst of the coronavirus pandemic. The acceleration of innovation in the world can still run even if it is carried out remotely because it keeps workers safe in the midst of the Corona pandemic. So it can be said that cloud technology or artificial intelligence is a tool that helps complete work indirectly or remotely so that workers can work without worrying about being affected by the coronavirus. (Center, 2020) The companies Google, Twitter, and Microsoft have made similar deals with Amazon. All work must take place even Facebook pays temporary workers, even if they are on leave due to illness, and pay them in full even though they work from home. The policies of this wellknown company are followed by many companies in the world, including in Indonesia. To stay productive and break the chain of Covid 19, it is necessary to work from home.

Productivity for organizations in an uncertain environment cannot stop, the leadership actually maintains the dynamic conditions so that everything continues to run, (Wahab et al. 2014) almost all companies review their respective plans and targets. Most of them try to adjust the current 
conditions by cutting activities that do not provide added values to organizational performance.

In line with these activities, efforts have been made to formulate new guidelines and policies, including work regulations and others. Actions taken by the company were also taken by X University, which wanted the title of excellence. Plans and programs and other activities continue to run in new ways accompanied by adjustments to budgets and external conditions. Adjustments are not easy for institutions and faculties at university. The condition of Covid encourages all units to create new guidelines and methods of work.

This was pursued because when the work was postponed in one part of the work unit it made it piled up and was not completed according to a schedule so that it not only created more workload for the institution but was detrimental to other units. This incident became a phenomenon in one of the units or institutions in Indonesian private universities. One example is the target and competency improvement program for lecturers experiencing a reduction. From previous records before Covid, every year on average, internal programs are held at least 4 times a year, but since Covid there has been no sign of the program going on as before. New policies to encourage lecturers to innovate are pending. They see that Covid comes with a lost program.

In addition, some lecturers, including the active group, asked about the applicability of policies related to research, service, and compensation that had been made and had been implemented. The fact that the information provided is confused and not consistent. At one time the policies and guidelines were conveyed and the guidelines were still valid, at other times it could not be used. When experiencing changes it is not accompanied by a definite decision letter. In fact, the contents of the policies often change without prior notification being published. The information provided between members in these institutions is different. The awards given between lecturers are not the same, including the provisions for participating in international seminars. There are no clear rules so far. Besides, whenever there is a sudden notification from an external party, it is not delivered quickly so that the lecturers finish the request hastily. This incident made the lecturers ask the institution, but the expected response was not satisfactory and even confused. The lecturers complained through the study program regretting this, they felt that this condition reduced the motivation to produce publications. From observations and surveys in the field, the list of complaints will increase in 2020 (Source of preliminary observations, 2020).

Observing these facts makes researchers felt it is important to understand and investigate these phenomena. This study aims to explain in detail the strategies of the leadership of research institutions in managing communication management and coordinating with its members. Although this theme is quite frequent, as in studies including (Gayeski and Rowland, 2005) Dialogues as a means of collective communication, (Kliem, 2007) Effective communication for project management, (Florida: Auerbach Publications. Pauliene, R., 2016) Interaction between managerial competencies and leadership in business organizations. From those studies conveyed that communication barriers can hinder company performance. This research is a new case that is important to be investigated at the X private university. The method used in this research is qualitative with a case study approach. Researchers made observations, field notes and conducted interviews with 11 competent informants. The informants were 5 deans and 2 heads of study programs, and 4 lecturers.

In the new normal era, because organizational members work from home cannot be an excuse that coordination cannot be done effectively. Leaders can communicate more often even though they are not conducted it face to face. The desire for creativity to build new cultures, it is necessary to carry out the leaders consciously by building effective communication and coordination management and always maintaining and ensuring that all members of the organization work collectively for common goals. (Hofstede et al. 2010).

In order to realize a superior university requires leaders who have passion, commitment and dreams that are in line with the goals of their organization. Therefore, leaders need to improve managerial competence in communicating effectively to influence inspire, motivate organizational members and create mutual respect and build collaboration to get synergistic results. In addition, the 
leader ensures that members of the organization are able to carry out tasks, supervise and to solve problems and to create a digital workplace (Digital Workplace) that is flexible, practical and transparent. The digital work environment can be done by making use of several available technologies so that work that has an impact on other work units is not delayed.

\section{Literature Review}

The Covid-19 coronavirus has become a global pandemic with consequences not only of economic inequality but has an impact on the regulatory system and policies of companies around the world in the face of an unprecedented crisis. The Coronavirus is spread throughout the content, not only affecting the work patterns of the government and the medical sector but work patterns and communication and coordination strategies as experienced by one of the higher institutions at a private university in Jakarta, Indonesia.

\section{Communication Organization}

Mastery of communication skills is very important, especially when someone is a member of an organization because these skills become a tool for interaction among members. Communication failure will result in misunderstanding, communication is the process of acting on the information. It is also a process where messages are sent and received simultaneously where we make sense of the world and share those feelings with others. In many cases, direct communication provides the best opportunity to clarify meaning and resolve uncertainties and misunderstandings (Beebe and Masterson, 2012), even according to (Ayub et al. 2014).

There is a strong relationship between communication and organization. All organizations consist of human resources and are interconnected through communication. It can be said that in an organization a large percentage of activities depend on the transmission of information (Axley, 1984). Communication makes systems and influences in organizations (Smith and Turner, 1995).

Organization communication is the activity of disseminating information through a network to recipients using a specific language which results in various types of social activities (Eisenberg et al. 2007). Through communication the leaders motivate, guide, and organize members to carry out their duties with the help of spoken or written words. Manager effectiveness is determined by his ability to listen and speak. He must be skilled in sharing his hopes and finding what others expect (Day et al. 2008).

Basically, organizational communication includes many forms of information and can be external or internal. External communication consists of, marketing, branding, advertising, customer relations, sales, media relations, public relations, business dialogue, etc. Meanwhile, internal communication includes communication of strategies, plans, company vision, guiding principles, corporate culture, shared values and exchange of ideas, employee motivation, etc. (Hynes, 2002). However communication takes place, the goal remains the same, namely to achieve organizational performance.

\section{Leadership and Communication}

Leadership is an important element in influencing a group towards achieving a vision or set of goals. (Robbins and Judge, 2008) Newstrom states that leadership is an important factor that helps individuals or groups identify their goals and then motivate them to achieve the goals that have been set. One of the functions of the leader is as a communicator in an organization. Leaders are required to be able to stimulate the team to take part in realizing the results of team work in their work units and have effective communication skills by paying attention to the state of communication of the people they lead because organizational activities can be carried out properly when communication competencies can be applied to improve the performance of the entire team in organizations (Senior, 1997). 
Therefore, communication competence is very important. Smooth communication is the main means of solving problems and even conflicts between organizational members with work performance, so efforts to improve communication within the organization are very important (Im et al. 2012)

Leaders are expected to be able to communicate both verbal and nonverbal communication. Good verbal communication can be done by using clear and understandable speech. Non-verbal communication can be done by communicating abstract concepts such as truth, justice, ethics, and religion non-verbally, for example using body language.

\section{Methods}

This research used qualitative case study research, explaining the practice of coordination and communication of institutional leaders to build communication and collaboration strategies with members of private university research institutes $\mathrm{x}$ and between other work units during the coronavirus pandemic. Research methods and procedures use a case study research design (Rony, 2017).

The research design begins with observing and identifying the practice of management of private university research institute and complaints submitted by the leaders of 5 faculty leaders as key informants and 2 heads of study programs and 4 lecturers. Observation data were documented to become field notes. Data collection was carried out by direct observation of institutional members in communicating in response to answers, and structured, semi-structured, and unstructured interviews related to the unit's responses to responding to and supporting research programs, community service, and publication.

\section{Participants}

There were 11 participants who were used as informants of this research. They were from 5 faculty leaders, 2 heads of study programs and 4 lecturers as key informants. In addition, there are informants found in the field who can be asked to add explanations related to a phenomenon called snowball sampling from the interview results, the number of informants involved 11 informants. They were all interviewed and the answers to the eight informants were saturated, in other words, the researcher had gotten the same answer as the previous informant.

\section{Interview Guidelines}

An interview guide was prepared to help researcher's direct informants to be more productive and involved in discussion groups (McLafferty, 2004). Researchers designed interview guides from general to specific questions (Kingry et al. 1990). This guide was previously used in the initial interview and was developed in subsequent interviews to obtain more detailed answers. After receiving feedback from interviews from several initial resource persons.

Table 1. Informant Data

\begin{tabular}{cccccc}
\hline Numb. & Name & Position & Age & Working Period of the entire & Faculty \\
\hline 1 & KK & Dean & 40 & 2 & X \\
2 & NBL & Dean & 33 & 6 & Y \\
3 & MT & Dean & 36 & 4 & X \\
4 & AL & Dean & 55 & 24 & D \\
5 & MH & Dean & 42 & 25 & E \\
6 & NTS & Head of study program & 34 & 2 & D \\
7 & ZKY & Head of study program & 35 & 3 & E \\
8 & DH & Lecturer & 32 & 4 & Y \\
9 & INA & Lecturer & 34 & 5 & Z \\
10 & RIA & Lecturer & 35 & 6 & T \\
11 & WK & Lecturer & 32 & 2 & \\
\hline
\end{tabular}


There are 3 main questions designed to be used in asking about (1) how is the leadership process communicating during the new normal period (2) how is the perception of the informant towards the leadership in coordination (3) how is the leadership's readiness to face the work from home at the institution?

\section{Data Validation}

To ensure the validity of the results of the interviews and the verbal accuracy of the informants' experiences, each interview was recorded by audio and video. The results of the interviews and observations of informants are contained in the full transcript.

Transcripts are described and carefully selected to then create appropriate categories by sorting thematic representations and divided into small units (phrases, sentences, or paragraphs), grouped into memos (Creswell and Clark, 2011), Researchers got 4 themes (Rony, 2017). The themes are a) Communication, b) Coordination, c) Adaptation and d) Cooperation before making a detailed report, a triangulation process is carried out through a focus group discussion by submitting research findings to 5 faculty leaders as key informants and 2 heads of study programs and 4 lecturers for approval the results of the interpretation of the researcher. The location of the interview was conducted at a private university.

Table 2. The theme of the interview results

\begin{tabular}{|c|c|c|}
\hline Numb. & Question & Theme \\
\hline 1. & $\begin{array}{l}\text { How do the leadership process communicate } \\
\text { during the new normal? }\end{array}$ & $\begin{array}{l}\text { Written } \\
\text { Verbal } \\
\text { Virtual }\end{array}$ \\
\hline 2. & $\begin{array}{l}\text { How do informants perceptions of the } \\
\text { leadership in coordination? }\end{array}$ & $\begin{array}{l}\text { Trust } \\
\text { Clarity } \\
\text { Monitoring } \\
\text { Organization Structure } \\
\text { Meeting skill }\end{array}$ \\
\hline 3. & $\begin{array}{l}\text { How are the readiness of the leadership to face } \\
\text { the work from home at the institution? }\end{array}$ & $\begin{array}{l}\text { Adaptation (job crafting, initiative) } \\
\text { Collaboration (trust, openness, ownership, } \\
\text { job description) }\end{array}$ \\
\hline
\end{tabular}

\section{Results and Discussion}

Becoming an Excellent University requires lecturers to provide work including publications of research and community service. The private university $\mathrm{X}$ encourages all its lecturers to produce sustainable works in various ways including giving a number of rewards when the lecturer fulfills the work. The provisions for getting a reward are outlined and described and approved by the leadership of the University as outlined in the form of guidelines that are ideally continuously updated according to the vision and mission of the University. Since August 2019, the management has agreed to make a new policy to encourage lecturers to produce more and more quality work. This good opportunity was welcomed by all lecturers at the faculty but the awaited guidelines were not completed until September 2020.

The absence of guidelines and other problems was conveyed by the officeholders as well as informants felt disadvantaged because several activities at the faculties were delayed. Many facts were conveyed from various faculties due to the unclear rules of a number of policies to replace research and community service incentives as outlined in the previous guidelines were changed and announced through oral statements, besides that, the members of the institution who handled were 
unable to explain in detail, especially during the corona era and their team was not present at the same time so that the information needed to be answered immediately, was forced to experience delays, even one simple question regarding the policy of agreeing to replace 2 (two) articles at once published in 2019, could not be answered directly. One question but the answers given are various. The policies implemented have not been uniform either. Treat one faculty with another faculty differently in replacing research incentives. Information needed from informants must be questioned again after a period of time, even though the informant hopes to get the information without having to ask again.

Some messages were distorted, there was a miscommunication between lecturers from faculty to members of the institution so that it needed several confirmations. Informants feel that there is a disconnected activity process, all questions, suggestions are not taken seriously and as if it is not something important, then there is never a collection of notes compiled by the leader or team so that complaints, suggestions, and notes are lost without a trace. The informants doubted that the message conveyed was not immediately recorded, discussed, and a solution was sought and executed. What is confusing is that the leadership of the institution and the team have not considered that a number of questions and complaints from lecturers are not crucial enough and easy to solve, but in fact, a number of questions that lead to guidelines have not been resolved properly and are not on target. Something that is considered important for lecturers is not necessarily considered important for members of the institution.

Regarding several incidents, the informants argued that the communication process between members had not been going well, the leadership had not yet built effective communication and meetings. Communication with leadership is closely related. An ideal leader has excellent communication skills because communication can determine whether a leader is successful or not in carrying out his duties (Fitz-Enz, 2000). Communication in an organization is the key so that all work can be carried out smoothly and harmoniously to achieve common goals. Agreed and determined, so that the element of coordination can automatically be implemented.

Leaders represent the most important source of information for their members in the organization because creating effective internal communication is very important to unite scattered goals (Kliem, 2007).

In addition, to resolve complaints, the agency can plan and target in the short term so that it does not have to wait for complaints that have accumulated and just been resolved. Planning and measurable targets help solve the problems faced by the unit. Although members of the institution carry out their responsibilities, they are still limited in routine work, the leadership should not give partial instructions but be able to monitor and clarify the extent to which work is in line with their expectations, besides that the work system is clear and measurable, especially for institutions that do not yet have infrastructure strong. Other considerations in addition to the competence of human resources, equipment, and tools, technology systems, information systems are items that need to be considered when implementing the work from home policy. A clear division of labor and the desire of members to work together in having high initiative are the keys to the success of the work units in completing their work.

Leaders do not maximize technology in coordination. Meetings are occasionally held but do not become a routine agenda, more than that there are no minutes as a measuring tool to monitor and serve as a guide in carrying out the next meeting. It seems that the use of technology media to overcome the limitations of face-to-face during a pandemic has not yet been carried out. In addition, the cooperation between leaders and members of the institution is not yet organized to support each other in serving and addressing the needs of lecturers, especially during the work from home (wfh) period.

It is not easy for organizations to conduct and create communication because they are not familiar with the work from a home method. Confusion of information and communication ethics leads to miscommunication, multiple interpretations, causing problems, especially for organizations 
that are new to using virtual communication systems in groups. It could be that some problems hang without a solution, there are times when members of the organization blame each other so that it delays a lot of work. Work that could have been handled quickly became slower. The function of the meaning creation process for interactions is not optimal. In other words, the benefits of communication as a means of completing work and adapting to the environment experience obstacles.

Communication activities in institutions aim to provide mutual understanding and equalize perceptions regarding activities and information among its members. Organizational communication is defined as the performance and interpretation of messages between communication units that are part of a particular organization. Organizational communication is the process of creating meaning for the interactions that create, maintain, and change organizations. (Bogdan Pirvulescu, 2015).

Leaders have their own role in conveying a message so that it can be conveyed effectively. The existence and understanding of the organizational structure are also very important because it will affect communication. Each member needs to understand their role so that they can regulate ethics in communication because it is the basis that needs to be considered for members of the organization in carrying out communication practices. The organizational structure guides how someone positions themselves in communicating, including taking part in the initiative to communicate in completing work. Communication is a medium between members to provide information to one another, both verbally and in other media. Communication is so very important, because in the implementation of the work of an institution this communication cannot be separated from coordination. Communication and coordination become a unitary work in carrying out work programs. Meanwhile, coordination is a human relationship in carrying out their duties. As emphasized by (Wong and Law, 2002), positive communication is needed to support success in the work environment. In other words, effective communication has the effect of increasing coordination efforts, which in turn improves team performance.

\section{Coordination Competence}

From the results of the interviews, the leadership and members of the institutions team experienced changes several times, because of this there was miscoordination, new members did not know about the past problems and were preoccupied with new problems. Old problems have not finished yet, new problems pile up. This condition becomes complicated when there are no systems and rules for institutional members to make detailed work handover reports related to work in scope by including work that is being processed, postponed, and will be carried out.

The impact of the absence of this system has made delayed work neglected, the guidelines have not been completed so that there are more problems affecting other units. A new research and service guidelines have not been completed and finished, causing communication between units to be less conducive, resulting in ongoing negative presumptions because the institution has never resolved the problem. Initiative and adaptation are important elements in accelerating coordination. Good leaders are expected to quickly adjust to the internal environment and the new scope of work and map their respective potentials and competencies, the behavior of the members of the institution (Hofstede et al., 2010). Other than that so that coordination is easier to do and can speed up the process of completing work (Hwang et al., 2015).

\section{Adaptation Competence}

Prior to the new habit era, leaders were required to master adaptability because the industrial era 4.0 encouraged organizational leaders to adapt to rapidly changing conditions. "As a leader, we need to foster the situation and map the various problems that occur. The above conditions indicate that the leadership of the institution did not take the initiative and even seemed to avoid problems. It seems that the members of the institution do not have the ownership because they do not respond to 
problems so that the expected solutions do not come.

Policy changes in one university are common place, but leaders need to show a quick response to decide what to do and be able to initiate zoom meetings with a group of relevant informants who need to get an explanation regarding to crucial rules. With the sophistication of technology, there is no reason to delay explaining things that need to be known to be conveyed to study programs and faculties in a planned manner with a clear agenda (Leenders et al. 2003).

The informant also added that formal activities in an effort to increase lecturers' knowledge regarding to research and community service were held very minimal. Activities during the pandemic which should have been able to continue became silent in accordance with the jargon of physical distancing that was echoed in the fight against corona. In fact, during a very dynamic period of change, members of this institution were no longer rigid about doing their jobs based solely on their job description. On the other hand, doing work out of the ordinary in a different way is called job crafting (Parker et al. 2010).

This is something that is very contradictory to the vision and mission of the University to achieve an Excellence University. In fact, the conditions in the era of disruption in the new normality have made adaptive competence increasing and even becoming Agility competence. (Joiner and Josephs, 2007).

Leaders with agility competencies are expected to adapt easily by adopting several methods that will make it easier for them to complete their work. One example of an activity that can be held is not using classical methods but transformed into regular distance learning methods.

\section{Collaboration}

The informant said that the team at the institution had not been maximal in conducting co-laboratories both within and between work units. They make sure when the information given to the faculty is different. The fact appears that the members of the teamwork in their respective fields. Do not move to other areas. Informant conveyed with endless confusion and astonishment why an easy problem was resolved in nearly 10 months.

Informants feel reluctant to conform to the institution because their welcome is not accompanied by a wholehearted desire to help, some members do not appear to have a passion and professional value in their work. The impact of communication and coordination, limited initiatives lead to low team collaboration. (Hammer, 2004)

Even though this institution is a forum that should provide support for lecturers to produce works. Openness in giving opinions should be responded to with a quick response. However, the response awaited was very slow, some informants hoped that before they asked questions, the answers or solutions had been answered. The collaboration that is expected to work well is still constrained because members of the institution are waiting for a decision from the leadership, the members' initiatives are not going well, while the leadership does not prioritize the work that must be completed first. From this phenomenon, it seems that the dream has not created a climate or culture that supports effective communication so that the impact is felt there is no mutual trust between its members and even institutions and other work units. (Allred et al. 2011) and (Jin et al. 2013)

More specifically, creating such a climate requires honesty, openness, good communication practices, and a responsibility to make communication more effective. Effective communication requires attention. This is not something that happens immediately but is developed as a result of the collaborative efforts of members of the organization and the leadership. In other words, communication in leadership is a very important element in achieving the success of the goals that will be achieved by an organization. (Im et al., 2012). Therefore, a leader must be good at communicating both verbally and non-verbally. Good communication can increase motivation, (Turner and Müller, 2005). So that the information submitted can be received well and this will be able to facilitate the implementation of work control and improve performance. In an institution, the leader is a communicator. Adaptive leaders generally have effective communication skills, so that 
they are able to stimulate participation and motivation to generate brilliant ideas and creativity when a culture of high synergy is formed. (Rony, 2019).

So that the information submitted can be well received and this will be able to facilitate the implementation of work control and improve performance. In an institution the leadership is a communicator and ideally the leader can create meaningful communication as conveyed by most of the informants in the interview:

In fact, we are often confused with the communication patterns of institutional leaders, the information provided is different from the information provided by organizational members. Some of the questions that were asked were answered without giving any resolution and solution. Never seems to change. I quite often give ideas, but the idea is never considered, maybe even ignored. If it's like this, it actually makes us lazy to connect and ask again.

One of the results of the interview implies that the leader does not adjust to solve problems that seem normative, and does not have the initiative to implement a communication strategy so that complaints from lecturers can subside.

From this research, the researchers made a model of performance constraints in the institution as follows:

This model describes efforts to improve performance in institutions to increase the satisfaction of lecturers. Several competency elements need to be considered and enhanced by the institution's leadership. Based on oral, written and virtual communication that effectively encourages openness, understands job descriptions, builds trust and a sense of responsibility can encourage collaboration between work units, besides that, coordination with several parties is easy to carry out because of the impact of effective meeting results followed by progress is monitored, the work is handled well because the members of the organization understand their roles and understand the tasks being carried out besides that the members of the organization are given the authority to be creative with full responsibility.

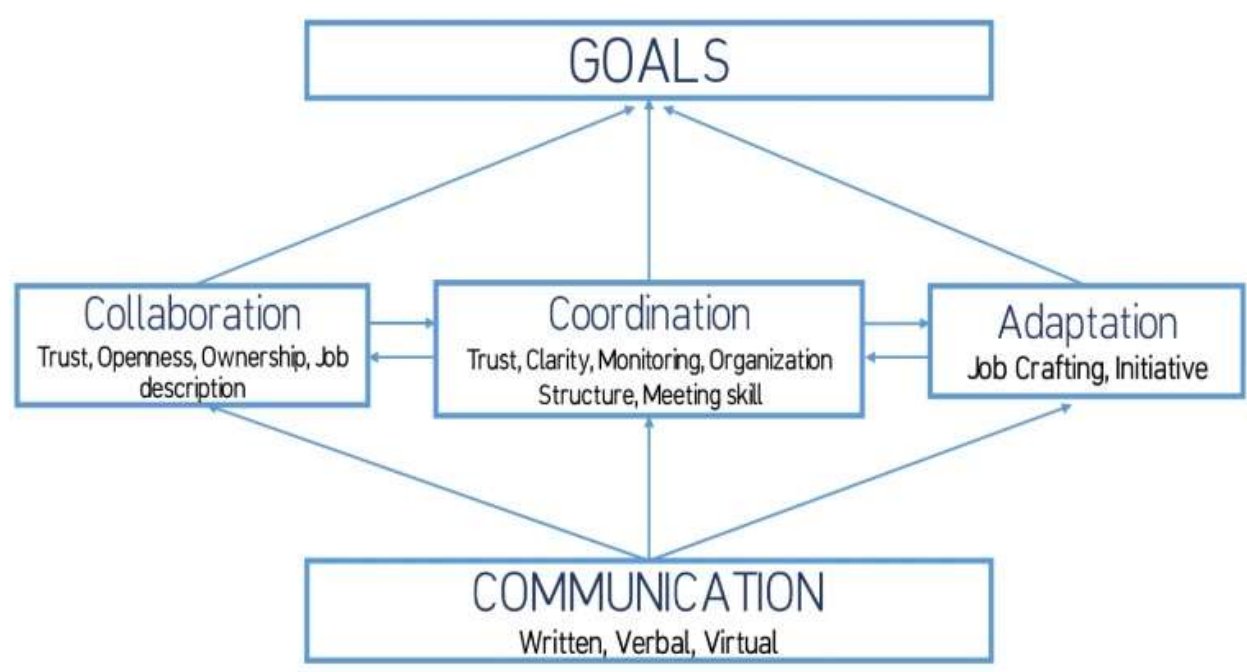

Figure 1. Elements to overcome Obstacles build Communication and Coordination at an Institution

\section{Conclusion}

The intitution member is accustomed to routine work and is carried out partially, so that it has an impact on the monitoring process that is not integrated and sustainable, thus hampering the time to 
complete the work. Ineffective communication is the biggest obstacle in completing work targets so that it has an impact on coordination, adaptation, collaboration. Leaders and their members have not taken full advantage of the presence of technology even though organizational communication in the new normal era apart from oral communication provides written and virtual communication in addition to the limited new policies work systems designed to create effective work. Initiative and adaptive competence are still limited in this institution.

Leaders and members are expected to be able to evaluate and make work plans according to the institution's targets. Ensure all members understand their work so that it makes it easier for them to have a sense of responsibility for their work, Conduct an evaluation of organizational members based on the work that has been achieved by members Utilize communication technology media with members and externals, such as by using e-mail, video conference, or the use of software / software to support and facilitate the management of crucial work as well as knowing how far the work has been completed by the team. Maximizing coördination and collaborating remotely to maintain commitment to the work that has been given. In addition, to set up regular communication, regular feedback is carried out. With this feedback, it can avoid problems that often occur in remote work such as misunderstandings, implicit assumptions, and conflicts.

This research has limitations because it is only conducted in one work unit or research institute and community service, therefore the results of this study cannot be generalized to other institutions at the University. For research to offer many benefits, it is suggested that this research be developed and continued to get other managerial competencies in maximizing performance in a university.

\section{References}

Allred, C. R., Fawcett, S. E., Wallin, C., \& Magnan, G. M. (2011). A dynamic collaboration capability as a source of competitive advantage. Decision sciences, 42(1), 129-161.

Axley, S. R. (1984). Managerial and Organizational Communication in Terms of the Conduit Metaphor. Academy of Management Review, 9(3), 428-437.

Ayub, S. H., Manaf, N. A., \& Hamzah, M. R. (2014). Leadership: Communicating Strategically in the 21st Century. Procedia - Social and Behavioral Sciences, 155(84), 502-506.

Beebe, S. A., \& Masterson, J. T. (2012). Chapter of Communicating in small groups: principles and practices. Communicating in Small Groups, 1-31.

Bogdan PIRVULESCU, P. (2015). The Importance Of The Management Communication Process. Internal Auditing and Risk Management, 101), 77-83.

Center, T. C. T. R. (2020). What is Telehealth? Retrieved from https://www.caltrc.org/telehealth/whatis-telehealth/

Creswell, J. W., \& Clark, V. L. P. (2011). Designing and Conducting Mixed Methods Studies. In Workshop for the 2011 Society for Social Work and Research annual meeting. 1-57.

Day, D. V., Harrison, M. M., \& Halpin, S. M. (2008). An integrative approach to leader development: Connecting adult development, identity, and expertise. Routledge.

Eisenberg, D., Golberstein, E., \& Gollust, S. E. (2007). Help-seeking and access to mental health care in a university student population. Medical Care. 45(7), 594-601.

Fitz-Enz, J. (2000). The ROI of human capital: measuring the economic value of employee performance. AMACOM Div American Mgmt Assn.

Gayeski, D., \& Rowland, G. (2005). Corporate conversation. In Dialogue as a Means of Collective Communication. 379-391.

Hammer, M. (2004). Deep Change: How Operational Innovation Can Transform Your Company. 
Harvard Business Review, 82(4):84-93.

Hofstede, G., Hofstede, G. J., Minkov, M., \& Cotté, J.-Y. (2010). Cultures et organisations: nos programmations mentales. Pearson Education.

Hwang, S. J., Quast, L. N., Center, B. A., Chung, C. T. N., Hahn, H. J., \& Wohkittel, J. (2015). The impact of leadership behaviours on leaders' perceived job performance across cultures: Comparing the role of charismatic, directive, participative, and supportive leadership behaviours in the U.S. and four Confucian Asian countries. Human Resource Development International. 18(3), 259-277.

Hynes, G. E. (2002). Strategies for Teaching Managerial Communication. Business Communication Quarterly. 65(3), 86-92.

Im, S. I., Park, J., \& Kim, H. S. (2012). The Effects of Nurse's Communication and Self-Leadership on Nursing Performance. Korean Journal of Occupational Health Nursing. 21(3), 274-282.

Jin, Y. H., Fawcett, A. M., \& Fawcett, S. E. (2013). Awareness is not enough: Commitment and performance implications of supply chain integration. International Journal of Physical Distribution and Logistics Management, 43(3), 205-230.

Joiner, B., \& Josephs, S. (2007). Leadership Agility: Five Levels of Mastery for Anticipating and Initiating Change. Reflections: The SoL Journal, 8(1), 44-51.

Kingry, M. J., Tiedje, L. B., \& Friedman, L. L. (1990). Focus groups: a research technique for nursing. Nursing Research, 39(2), 124-125.

Kliem, R. L. (2007). Effective communications for project management. CRC Press.

Leenders, R. T. A. J., Van Engelen, J. M. L., \& Kratzer, J. (2003). Virtuality, communication, and new product team creativity: A social network perspective. Journal of Engineering and Technology Management - JET-M. 20(1-2), 69-92.

McLafferty, I. (2004). Focus group interviews as a data collecting strategy. Journal of Advanced Nursing. 48(2), 187-194.

Parker, S. K., Bindl, U. K., \& Strauss, K. (2010). Making things happen: A model of proactive motivation. Journal of Management. 36(4), 827-856.

Robbins, S. P., \& Judge, T. A. (2008). Organizational Behavior: Global Edition. Pearson.

Rony, Z. T. (2017). Siap Fokus, Siap Menulis Skripsi, Tesis, Disertasi (Jurus Mudah Gunakan Metode Kualitatif Tipe Studi Kasus). (S. Kusumawati, Ed.) (First). Jakarta: Pusat Studi Sumber Daya Manusia (PSSDM).

Rony, Z. T. (2019). Generation y challenges in becoming innovative leaders at organization in the 21 st century. International Journal of Recent Technology and Engineering, 8, 789-794.

Senior, B. (1997). Team roles and team performance: Is there "really" a link?. Journal of Occupational and Organizational Psychology. 70(3), 241-258.

Smith, R. C., \& Turner, P. K. (1995). A social constructionist reconfiguration of metaphor analysis: An application of "scma" to organizational socialization theorizing. Communication Monographs. 62(2), 152-181.

Tian, S., Hu, N., Lou, J., Chen, K., Kang, X., Xiang, Z., Zhang, J. (2020). Characteristics of COVID-19 infection in Beijing. Journal of Infection, 80(4), 401-406.

Turner, J. R., \& Müller, R. (2005). The Project Manager's Leadership Style as a Success Factor on Projects: A Literature Review. Project Management Journal. 36(2), 49-61. 
Obstacles build communication and coordination of institution in the university: a qualitative study

Wahab, S., Shahibi, M. S., Ali, J., Bakar, S. A., \& Amrin, A. N. A. (2014). The Influence of Leaders Orientation on Event Management Success: Event Crews Perception. Procedia - Social and Behavioral Sciences. 109, 497-501.

Wong, C. S., \& Law, K. S. (2002). The effects of leader and follower emotional intelligence on performance and attitude: An exploratory study. Leadership Quarterly. 13(3), 243-274. 